\title{
Kötésrend- és vegyértékindexek
}

\author{
MAYER István \\ MTA Természettudományi Kutatóközpont, Szerves Kémiai Intézet, 1117 Budapest, Magyar tudósok körútja 2.
}

\section{Bevezetés: a kezdetek}

Én azt mondhatnám, hogy majdhogynem úgy kerültem a kvantumkémiába, „mint Pilátus a krédóba”: eredetileg rádiófizikusként végeztem Harkovban, a diploma- munkámban (és az első időben az MTA KKKI-ban) ESR-spektroszkópiával foglalkoztam. A kísérleti munka mellett érdeklődtem az ESR spektrumokban megfigyelhető hiperfinom felhasadások elméleti értelmezése iránt is, ami lényegében egyfajta (alkalmazott) kvantumkémia. Oktatóim a spektrumok elméletével nemigen foglalkoztak, de meg tudtak adni a kiinduláshoz szükséges néhány hivatkozást. Az egyetemen kvantummechanikát persze tanultam, de kvantumkémiát természetesen nem, úgyhogy önállóan kellett az alapvető fogalmakkal megismerkednem. (A későbbiekre is igaz, hogy a kvantumkémiában lényegében mindig autodidakta voltam.) Nagy segítségemre volt Veszelov könyvecskéje ${ }^{1}$, amely kiválóan foglalta össze az akkori (1966/67-es!) legfontosabb elemi kvantunkémiai ismereteket.

A szakdolgozatomban megkezdett elméleti vizsgálatokat a KKKI-ba kerülve is folytattam. Eredményeim nagyon megtetszettek Ladik Jánosnak, az Elméleti Kémiai Csoport akkori vezetőjének, úgyhogy elérte, hogy akadémiai gyakornoki időm lejártával, 1970 februárjától az ő csoportjában kapjak segédmunkatársi állást. Mindenekelőtt el kellett kezdenem szisztematikusan kvantumkémiát tanulni. Belefogtam a Hartree-Fock (HF) egyenletek levezetésének tanulmányozásába Bethe könyve ${ }^{2}$ alapján, és ellentmondást véltem felismerni azzal, amit a variációszámításról matematikából tanultam. Amikor fenntartásaimat elmondtam Ladiknak, s tisztáztuk, hogy nem a HF egyenleteket, csak a (standard) levezetést tartom problémásnak, akkor azt mondta, hogy „Akkor csinálj jobbat!” Néhány napon belül sikerült is egy egyszerübb és jobb levezetést ${ }^{3}$ megadnom az ún. Brillouin-tétel alapján - ez az eredmény fordulópontot jelentett az életemben, lényegében akkor dőlt el, hogy kvantumkémikus leszek. Mindmáig nagy előszeretettel foglalkozom a különböző levezetésekkel, úgy, hogy igyekszem tisztázni a nüanszokat is, de nem „túlmatematizálni” a levezetéseket - ennek eredménye lett 2003-ban megjelent, kifejezetten a levezetésekkel foglalkozó ,haladó” tankönyvem ${ }^{4}$.

\section{Az EHF módszer fejlesztése}

Ladik Uppsalaból, a Per-Olov Löwdin csoportjánál töltött hosszabb tanulmányútjáról hozta haza az ún. „extended Hartree-Fock” (EHF) módszer problémáját. Ez egy nagyon ígéretesnek látszó módszer volt, mert úgy teszi lehetővé az elektronkorreláció részleges figyelembevételét, hogy megőrzi a HF módszer szemléletes egyelektron-képét. A kiindulás mindkét esetben egyetlen determináns, de amíg a HF esetben ezt a determinánst magát használjuk a számításokban, az EHF esetben ezt előzőleg még egy ún. spinprojekciónak is alávetjük. Ez teszi lehetővé, hogy feloldjuk a térbeli elektronpályák kétszeres betöltésére vonatkozó megszorítást, de mégis megőrizzük a hullámfüggvény korrekt spin-szimmetriáját. A spinprojicionált determináns azonban egy elég bonyolult matematikai objektum, és ezért nem voltak ismeretesek az optimális elektronpályákat meghatározó EHF-egyenletek. Nekem sikerült megtalálnom az EHF esetre vonatkozó általánosított Brillouin-tételt, és ennek alapján többévi munkával levezetnem, majd beprogramoznom a keresett EHF-egyenleteket - nem csak az akkor még széleskörüen használt szemiempirikus elméletek esetére, de ab initio szinten is. (Jellemző az 1970-es évek számítástechnikai lehetőségeire, hogy a legnagyobb rendszer, amire ab initio EHF számításokat lehetett végezni Magyarországon, az a hatelektronos $\mathrm{BH}$ molekula volt, de ennél is trükköket kellett alkalmaznom.) Az EHF módszerrel kapcsolatos eredményeim alapján kaptam meg 1978-ban a kandidátusi fokozatot, s a témakört egy nagy összefoglaló ${ }^{5}$ publikálásával zártam le.

\section{A CHA módszer}

A 70-es évek végére az EHF módszer fejlesztését lényegében befejezettnek éreztem, és gondolkozni kezdtem egy új téma kiválasztásáról. Számot vetettem azzal, hogy Magyarországon a COCOM-lista (a kelet-európai országokra vonatkozó embargó) miatt nem lehettünk versenyképesek „számításos” kvantumkémiai területen nem voltak hozzáférhetőek az ehhez szükséges számítógépek, és még nem volt Internet, hogy külföldi gépeken futtassuk a programokat. Ezért olyan területeket kerestem, amelyek elsősorban szellemi kapacitást igényelnek. Felismertem, hogy a molekulák kémiai, ill. fizikai szintű tárgyalása között jelentős szemléleti különbség van: a fizikus a molekulát kölcsönható részecskék atommagok és elektronok - rendszerének tekinti, míg a kémikus egymással kémiai kötésben lévő atomok együtteseként írja le. Természetesen a maga helyén mindkét kép helyes, ezért arra a konklúzióra jutottam, hogy elméleti módszereket kell keresni e kétféle leírás összekapcsolására.

A probléma vizsgálatára egy újfajta formalizmust fejlesztettem ki, a nem-ortogonális pályákra vonatkozó másodkvantálást ${ }^{6,7}$. A másodkvantálás alkalmazására azért volt szükség. mert a szokásos (térbeli) reprezentációban a

*e-mail: mayer.istvan@ttk.mta.hu

125. évfolyam, 3. szám, 2019. 
Hamilton-operátor az összes elektron koordinátáit tartalmazza, amelyek nem rendelhetők az egyes atomokhoz, míg a kvantumkémiában szokásos atomcentrált bázisok bázisfüggvényei (bázispályái) és az ezekhez tartozó keltő, ill. eltüntető operátorok igen. Viszont azért kellett a másodkvantált formalizmust általánosítani, mert a szokásos másodkvantálás ortonormált egyelektron-függvényekre vonatkozik, viszont a kvantumkémiában használt bázisok nem azok. Az elemi kvantumkémiából ismert, hogy a különböző atomok pályáinak átfedése kémiailag jelentős effektusokért felelős, ezért az kémiai jelenségek elméleti analíziséhez ezeket az átfedéseket explicite kell kezelni, s nem lenne célravezetô áttérni valamilyen ortogonalizált bázisra. $\mathrm{Az}$ ún. biortogonális bázis bevezetésével a nem-ortogonális formalizmus kifejezései egyébként formailag alig bonyolultabbak, mint amit az ortogonális esetben megszoktunk.

A másodkvantált Hamilton-operátor a keltő és eltüntető operátorokon kívül a bázisfüggvényekre vonatkozó egy- és kételektronos integrálokat tartalmazza. (A nem-ortogonális esetben, ha csak az eredeti bázisfüggvényekre vonatkozó integrálokat akarjuk használni, még megjelennek az átfedési mátrix inverzének elemei is.) $\mathrm{Az}$ egyelektonos integrálokban két bázispálya és egy atommag, a kételektronosokban négy bázispálya szerepel. Ennek megfelelően az integrálok akár három- ill. négycentrumosak is lehetnek. A kémiai tapasztalat viszont azt mutatja, hogy a molekulákban nem szükséges három- ill. négyatomos primer kölcsönhatásokat feltételezni, a kollektív effektusokat mint az egy- és kétcentrumos kölcsönhatások interferenciáját lehet tárgyalni. (Pl. az aromaticitás jelenségét kvalitatíve már az egyszerü Hückel elmélet szintjén is értelmezni lehet.) A három- és négycentrumos integrálok miatt még az átfedő bázisra felírt Hamiltonoperátor sem alkalmas önmagában arra, hogy a molekulák fizikai és kémiai leírásmódjai közötti kapcsolatot megfelelően leírja. Ezt a problémát egy olyan speciális projekciós technikával sikerült kezelnem ${ }^{6}$, amely lehetővé tette, hogy a három- és négycentrumos effektusokat a lehető legjobban egy- és kétcentrumos tagok összegeként közelítsük. A projekciós közelítés úgy történik, hogy az egyill. kételektronos integrálokat a „ket” részben szereplő bázisfüggvény(ek) szerint - a magvonzási integrálok esetén az érintett atommagot is figyelembe véve - kategorizáljuk egy- vagy kétatomos jellegűnek, és a „bra” részben szereplő függvényeket a szóban-forgó atom(ok)on centrált bázisfüggvények alterébe vetítjük.

Ezekkel a közelítésekkel a molekula Hamilton-operátorát egy- és kétatomos tagok - valamint az integrálközelítések hibáját tartalmazó „,báziskiterjesztési” korrekciós tagok összegére lehetett felbontani. Ezt a felbontást Surján Péter javaslatára „kémiai Hamilton operátor” formalizmusnak (,chemical Hamiltonian approach, CHA) neveztem el.

A közelítések hibája azt tükrözi, hogy az egy-egy atomon, ill. atompáron centrált véges bázisok nem teljesek. Ezért a Hamilton-operátort úgy is fel lehetett bontani, hogy a „báziskiterjesztési” korrekciós tagok analógiájára különválasszuk azokat a tagokat, amelyek intermolekuláris külcsönhatások vizsgálatánál az ún. „báziskiterjesztési hibát" (basis set superposition error, BSSE) okozzák. Az intermolekuláris esetre vonatkozó $\mathrm{CHA}$ formalizmus ${ }^{6}$, lehetővé teszi a BSSE a priori kiküszöbölését. A CHA formalizmusnak intermolekuláris kölcsönhatásokra való alkalmazásával intenzíven foglalkoztam mintegy húsz éven keresztül, szoros együttmüködésben többek között Surján Péterrel (Budapest), Vibók Ágnessel (Debrecen), Pierre Valironnal (Grenoble), ill. Pedro Salvadorral (Girona).

\section{A kötésrend-index definíciója}

Miután elvégeztük a Hamilton-operátor egy- és kétatomos (és korrekciós) tagokra való felbontását, a kétatomos tagokat érdemesnek látszott különböző fizikai jellegü tagokra még tovább bontani ${ }^{6}$. További mondanivalónk szempontjából az a tag érdekes, amely a kétatomos elektron-elektron kölcsönhatásokat a legegyszerübb ponttöltés-közelítésben írja le. Ezt úgy kapjuk meg, hogy a $\left[X^{A}{ }_{\mu}(1) X^{B}{ }_{V}(2) \mid X^{A}{ }_{\rho}(1) X^{B}{ }_{T}(2)\right] \quad$ kétcentrumú kételektronos elektrontaszítás1 integrálokat aszimptotikus értékükkel,

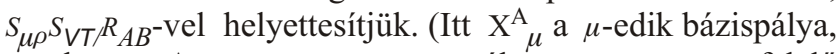
amely az A atomon van centrálva, $S_{\mu \rho}$ a megfelelö bázispályák átfedési integrálja, $R_{A B}$ pedig az $\mathrm{A}$ ás $\mathrm{B}$ atomok közötti távolság.)

Ha kiszámítjuk a molekula energiáját, mint a Hamiltonoperátornak az adott közelítésben kapott hullám- függvényéhez tartozó várható értékét, akkor az természetesen egyenlő lesz az egyes komponensek várható értékének összegével. (Az évek folyamán több ilyen energiafelbontási sémát is kidolgoztam $\mathrm{s}$ alkalmaztam, de ezek tárgyalása a jelen munka kereteit meghaladná.) A pontszerü közelítésben (a magtaszítás figyelembe- vételével) számolt energiakomponens a kétatomos kölcsönhatások egyik vezető tagja, sokszor ez a legfontosabb. Hartree-Fock hullámfüggvények használata esetén ez az energiakomponens két tag összege. Az egyik egyszerüen a két atom pontszerünek tekintett Mulliken-féle bruttó atomtöltésének elektrosztatikus kölcsönhatása, a másik a nem-klasszikus kicserélődést tükrözi. Ez a kétatomos kölcsönhatás kicserélődési részének a vezető tagja ${ }^{6}$.

Hamarosan felismertem ${ }^{7}$, hogy ennek a vezető kicserélődési energiatagnak az a tulajdonsága van, hogy ha elhagyjuk a képlet elején álló $-1 /\left(2 R_{A B}\right)$ koefficienst, akkor a fennmaradó tag a legegyszerübb zárt-héjú kétatomos molekulákra (minimális bázisok használata esetén) eggyel, kettővel vagy hárommal lesz egyenlő, aszerint, hogy a molekulában egyes-, kettős- vagy hármaskötés van. (Mint később kiderült, a $\mathrm{C}_{2}$ molekula különleges elektronszerkezete miatt ez alól kivétel.) Érdemesnek látszott az így kapott kifejezés tulajdonságait megvizsgálni bonyolultabb, többatomos, molekulákra és más, nagyobb bázisokra is. Azt tapasztaltam, hogy a kapott számok mindig közel voltak a kémikusok által a különböző kötések kötésrendjére elfogadott értékekhez, ezért érdemes volt ezeket mint az adott kvantumkémiai módszerrel kapott kvantumkémiai kötésrend-indexeket definiálni. 
Zárt-héjú HF hullámfüggvényre a kötésrendet az egyszerü

$$
B_{A B}=\Sigma(\mu \in A)^{\Sigma}(v \in B)^{(\mathbf{D S})} \mu v^{(\mathbf{D S})} v \mu
$$

kifejezés adja $\mathrm{meg}^{7}$, ahol D a szokásos (spinmentes) sürüségmátrix, $\mathbf{S}$ az átfedési mátrix, és a $\mu \in A$ megszorítás azt jelzi, hogy a $\mu$ összegző index az A atomon centrált pályákon fut végig. Nyílt-héjú rendszerek esetén (beleértve az UHF esetet is) ehhez még hozzá kell adni egy ugyanilyen, de a spinsürüség-mátrixszal képzett tagot is.

\section{A kötésrend-index néhány tulajdonsága}

Papírral-ceruzával be lehetett látni, hogy egy szigorúan lokalizált polarizálatlan kételektronos kötéshez valóban egzaktul 1-gyel egyenlő kötésrend tatozik. Érdekes módon, ebben nincs különbség aszerint, hogy egy kötőpályáról vagy egy lazítópályáról van-e szó. (Szerencsére általában a kötőpálya töltődik be először, s így ez a kétértelműség nem okoz problémát.) Ha csak egy elektron van a molekulapályán (pl. $\mathrm{H}_{2}{ }^{+}$ion), akkor a kötésrend pont $1 / 2$. Ugyanígy az is levezethető, hogy ha ugyanazokból az atompályákból képzett kötő és lazító molekulapályák egyaránt be vannak töltve két-két elektronnal, akkor a kötésrend 0 (v. ö. $\mathrm{He}_{2}$ rendszer), vagyis a két pálya egymás hatását kompenzálja. Ez teljes összhangban van azzal, hogy egy ilyen hullámfüggvény a pályák uniter transzformációjával két szigorúan az egyes atomokon lokalizált pályával is felírható. Az egymásra ortogonális atompályákból képzett molekulapályák hatása egyszerüen összeadódik. Így a legegyszerübb esetekben a $B_{A B}$ kötésrend egyenlő a „kémikusi kötésmultiplicitással”, $\left(N_{k \ddot{o ̈ t o}}-N_{\text {lazitó }}\right)^{/ 2}$-vel, ahol $N_{k o ̈ t o ̋ ~}$ és $N_{\text {lazitó }}$ egyelő a kötő- ill. lazítópályákon lévő elektronok számával. (A $\mathrm{C}_{2}$ molekula esetén azért nem kapunk egészszámú kötésrendet, mert a betöltött kötő és lazító pályapár nem szigorúan ugyanazokból a hibrid atompályákból épül fel, s így egymás hatását csak részben kompenzálják. )

Hasonlóan lehetett azt is papíron belátni, hogy egy polarizálatlan kételektronos-háromcentrumos kötés két szélső pillér-atoma között akkor is létrejön egy 1/4-del egyenlő kötésrend, ha ezek az atomok messze vannak ahhoz, hogy számottevő közvetlen kölcsönhatásuk legyen egymással, A diborán molekulában két ilyen kötés van, ezért a két bór atom között 1/2-es kötésrend várható, amit a konkrét számítások vissza is igazolnak. Ez az 1/2-es kötésrend lényeges a diborán molekula szerkezetének és stabilitásának megértéséhez.

Könnyen belátható, hogy ha a kötésrend-index kifejezését ortonormált bázisra és valós bázisok és pályakoefficiensek esetére alkalmazzuk, akkor az a szemiempirikus CNDO elmélet keretében a kötéserősség jellemzésére használt Wiberg-index ${ }^{8}$ képletére egyszerüsödik. Ily módon a kötésrend-index a Wiberg-index ab initio szintü természetes általánosításának tekinthető. Ennek megfelelően széleskörüen alkalmazzák is a különböző kémiai kötések erősségének jellemzésére a legkülönbözőbb, számomra mint fizikus számára már tökéletesen követhetetlen bonyolult kémiai problémák vizsgálatánál. (Fontos megjegyezni, hogy csak szigorúan azonos bázissal számolt kötésrendeket szabad összehasonlítani.)

A kötésrend-indexnek egy érdekes „statisztikus” interpretációját adta meg a Giambiagi házaspár ${ }^{9}$. Ha egy kétcentrumos molekulapályát tekintünk, akkor ennél az egyik atomon csak úgy nőhet az elektrontöltés, ha a másikon lecsökken, vagyis a két atomon lévő elektrontöltés egymással szigorúan korrelált. Egy ilyen kételektronos pálya egy egyes kötést ír le; ha két ilyen pálya van az atomok között, akkor kettős kötéssel van dolgunk, stb. Nos, meg lehetett mutatni, hogy a kötésrend-index a két atom elektrontöltése közötti korreláció mértéke, vagyis megadja, hogy a molekula hullámfüggvénye effektive hány kompenzálatlan kötőpályát tartalmaz a két atom között.

A kötésrend-indexnek egy absztraktabb matematikai definícióját is vizsgáltam ${ }^{10}$. Ez a másodrendű sürüségmátrix vizsgálatán alapult. Ismeretes, hogy egydetermináns hullámfüggvények használata esetén a $\rho_{2}$ másodrendü sűrüségmátrix felírható a $\rho_{1}$ elsőrendű sűrűségmátrix segítségével:

$$
\rho_{2}\left(1,2 ; 1^{\prime}, 2^{\prime}\right)=\rho_{1}\left(1,1^{\prime}\right) \rho_{1}\left(2,2^{\prime}\right)-\rho_{1}\left(2,1^{\prime}\right) \rho_{1}\left(1,2^{\prime}\right)
$$

Itt az első tag az ún. direkt vagy Coulomb komponens, a második pedig a kicserélődést írja le. Egydetermináns hullámfüggvény esetén ennek a kicserélődési tagnak az integráljára érvényes, hogy

$$
\iint \rho_{1}(2,1) \rho_{1}(1,2) d \tau_{1} d \tau_{2}=N,
$$

ahol $N$ az elektronok száma a molekulában. Ha a $\rho_{1}$ elsőrendű sűrüségmátrixot felírjuk a sürüségmátrix(ok) és a bázisfüggvények segítségével, s ezeket az atomok alapján csoportosítjuk, akkor az integrál ilyen felbontásának kétatomos komponensei éppen a kötésrendekkel egyenlők.

Mivel lassan egy évszázada tudjuk, hogy a kémiai kötés egy „par excellence” nem-klasszikus, csak kvanummechanikailag értelmezhetö jelenség, nem meglepő, hogy a kötésrend a másodrendű sürüségmátrix (lényegében az elektronok pár-sürüsége) nem-klasszikus kicserélődési komponensével kapcsolatos. Érdemes ezt egy kicsit energetikai szempontból is értelmezni ${ }^{11}$.

Mint már említettem, két atom közötti kölcsönhatásban kiemelt szerepe van a bruttó atomi töltések közötti elektrosztatikus (Coulomb) kölcsönhatásnak. Ha két atom között van egy delokalizált kötés, akkor az ezen lévő elektron(ok) mindkét atom töltéséhez hozzájárulnak, s így befolyásolják azok Coulomb kölcsönhatását. Azonban egy elektron nem hat elektrosztatikusan kölcsön önmagával, vagyis az elektron-elektron taszításból le kell vonni azokat a komponenseket, amelyek az azonos elektronokhoz tartozó kölcsönhatásokból származnak. Ezeknek az „öntaszítási” tagoknak az elhagyása csökkenti a rendszer energiáját, vagyis hozzájárul az atomok közötti kötés kialakulásához. 
Az elektronok öntaszítása a kicserélődési energia vezető komponense, egyelektronos és szingulett kételektronos rendszereknél az egyedüli összetevője. Ily módon megállapítható, hogy a kicserélődés szerepe a kémiai kötés leírásában elsősorban az öntaszítási energia megfelelő figyelembevételének tudható be. (Megjegyezzük, hogy általános sokelektronos esetben az öntaszítást nem lehet szigorúan különválasztani a kicserélődés többi komponensétől.)

\section{A vegyérték-index}

Wiberg $^{8}$ bevezette a $b_{\mu}=2 q_{\mu-} q_{\mu}^{2}$ mennyiséget, ahol $q_{\mu}$ a $\mu$-edik pályán lévő elektrontöltés. $b_{\mu}$ jellemzi a $\mu$-edik pálya kötőképességét: $b_{\mu}=0$ mind egy üres, mind egy kétszeresen betöltött pályára $\left(q_{\mu}=0\right.$ ill. 2), míg

maximális értékét (1-et) egy egyszeresen betöltött pálya $\left(q_{\mu}=1\right)$ esetén éri el. Egy egyszeresen betöltött pálya épp egy kötést képes létrehozni. Ha összeadjuk az adott atomon centrált pályákra vonatkozó $b_{\mu}$ mennyiségeket, és levonjuk az atomon belüli kötésrendeket, akkor megkapjuk az atom vegyértékét ${ }^{7}$ :

$$
\begin{gathered}
V_{A}=2 Q_{A}-\Sigma_{(\mu, v \in A)^{(\mathbf{D S})} \mu \nu(\mathbf{D S}) v \mu} \\
Q_{A}=\Sigma_{(\mu \in A)^{a} \mu}=\Sigma_{(\mu \in A)^{(\mathbf{D S})} \mu \mu} \text { Ittegyenlő az A }
\end{gathered}
$$

atom Mulliken-féle bruttó elektronpopulációjával. Az atomon belüli kötésrendek levonását a szemléletes megfontolásokon kívül az is indokolja, hogy ez biztosítja azt, hogy az atomok vegyértéke invariáns legyen a molekula egészének elforgatására.

A sürüségmátrix idempotenciáját kihasználva be lehet látni, hogy kétszeresen betöltött pályák használata esetén a vegyérték egyenlő az adott atomnak az összes többi atommal alkotott kötésrendjének összegével:

$$
V_{A}=\Sigma_{(B ; B \neq A)^{B} A B}
$$

Általános (nyílt-héjú vagy korrelált) esetben a jobboldalon megjelenik még egy mennyiség, az $F_{A}$ szabad vegyérték-index. Ezt egydetermináns esetben ki lehet fejezni a spinsürüség-mátrix segítségével, azaz az atom gyökös jellegének mértéke. (Azonban nem lehet közvetlenül azonosítani az atom lokális spinjével - a lokális spinek kérdése egy külön terület, aminek fejlődése kifejezetten kalandosnak volt nevezhető; az ezzel kapcsolatos eredményeinket újabb könyvemben ${ }^{12}$ foglaltam össze.)

A vegyérték-index értéke közel szokott lenni a kémikus által definiált egész számokhoz. Megfelelően flexibilis ( $d$-pályákat is tartalmazó) bázisok használata esetén ez így szokott lenni hipervalens atomok (pl. 4- ill. 6-értékú kén) esetén is. A vegyérték-indexet felbontva $s-, p$-, $d$ - stb. komponensekre, mélyebb betekintést nyerhetünk az atomok körüli elektronszerkezetbe. Így - a várakozásoknak megfelelően - az első sor-béli atomoknál az s-típusú bázispályák együttesen egyhez közeli hozzájárulást adnak a vegyértékhez, míg a $p$-pályák legfeljebb hármat. Ezeknél a $d$-pályák valóban csak polarizációs függvények, hozzájárulásuk a vegyértékhez csekély. Hipervalens kénatomok esetén azonban az $s$ - és $p$-pályák kötésbe lépése során egy nagyon pozitív atom alakul ki, és az erre a pozitív törzsön kívüli $d$-pályákra való viszonylag kismértékü „back-donation” rendkívül fontos a végső kötésszerkezetnek - és az atom eredő vegyértékének - kialakulásában.

\section{Háromdimenziós analízis}

Sajnálatos módon nem létezik egyértelmü szigorú definíció arra, hogy mit is jelent egy atom a molekulán belül. Az eddigiekben úgy végeztük a különböző mennyiségek vizsgálatát, hogy az egyes atomokhoz az atommagot és az azon centrált bázisfüggvényeket rendeltük hozzá. Ezt a megközelítést Hilbert-térbeli analízisnek szokták nevezni. Egy másik lehetséges megközelítés az ún. háromdimenziós (3D) analízis, amikor az atomot az atommaggal és a körülötte lévő térrésszel azonosítjuk. Ennek a térrésznek lehetnek „elvágólagos” határai, amikor is a $3 \mathrm{D}$ tér minden pontja szigorúan az egyik atomhoz tartozik (ilyen a széleskörüen használt Bader-féle elmélet), vagy tekinthetjük úgy, hogy a szomszédos atomok térrészei fokozatosan mennek át egymásba. Ilyenkor az atomok közötti pontok fokozatosan változó mértékben mindkét (vagy akár több) atomhoz tartoznak egyszerre - ezt a megközelítést „fuzzy atom” formalizmusnak nevezzük. A kétféle 3D megközelítés közös elméleti keretben tárgyalható: a tér minden $\mathbf{r}$ pontjában minden $\mathrm{A}$ atomhoz hozzárendelünk egy-egy $\mathrm{w}_{\mathrm{A}}(\mathbf{r}) \quad$ súlyfüggvényt, amelyekre kikötjük, hogy $0 \leq \mathrm{w}_{\mathrm{A}}(\mathbf{r}) \leq 1$ és ugyanakkor $\Sigma_{A^{\mathrm{w}} \mathrm{A}}(\mathbf{r})=1$. A Bader-féle elméletben minden pontban egy $\mathrm{w}_{\mathrm{A}}(\mathbf{r})=1$ és az összes többi 0 , míg a fuzzy atom formalizmusban a súlyfüggvények folytonosan változó értékeket vesznek fel. (Különböző fuzzy atom súlyfüggvények használatosak, ennek részletezésére itt nem érdemes kitérni.)

A 3D esetben a kötésrend- és vegyértékindexek bevezetése a fent vázolt módon a másodrendű sürüségmátrix kicserélődési részének a felbontása alapján történhet ${ }^{13}$, csak most a felbontás a súlyfüggvények segítségével történik. A képletek is elég hasonlóak, itt az összegeknek az adott atomon centrált bázisfüggvényekre való megszorítása helyett megjelenik az atomi átfedési mátrix, melynek eleme $\mathrm{S}^{A} \mu v=\left\langle X_{\mu}(\mathbf{r})\left|\mathrm{w}_{\mathrm{A}}(\mathbf{r})\right| X_{v}(\mathbf{r})\right\rangle$. A kapott számértékek jellegükben nagyon hasonlóak a Hilbert-tér analízis keretében kapottakhoz, ami újra igazolja, hogy jó úton kerestük a kémiai kötésrend és vegyérték fogalmának kvantummechanikai megfelelőit. Érdemes megemlíteni, hogy a fuzzy atom formalizmus segítségével még akkor is sikerült kémiailag ,értelmes” kötésrend- és vegyérték- indexeket kinyerni a hullámfüggvények feldolgozásából, amikor a kvantumkémiai számításokat síkhullám-bázisban - vagyis bármiféle atom-centrált bázisfüggvények felhasználása nélkül - végeztük ${ }^{14}$.

Érdemes megjegyezni, hogy kidolgoztunk egy ún. ,atomi egységfelbontás" formalizmust ${ }^{15}$, amely lehetővé tett olyan absztrakt definíciókat, hogy a Hilbert-tér analízissel kapott, 
ill. a 3D analízissel kapott képletek egy közös általános eredmény speciális eseteként formális behelyettesítéssel voltak visszakaphatók.

\section{Korrelált hullámfüggvények}

Az eddigi megfontolások egydetermináns (HF vagy DFT) hullámfüggvényekre vonatkoztak. Felvetődik az a kérdés, hogy miként kell általánosítani a kötésrendek, ill. vegyértékek számítását a korrelált, többdeterminánsos hullámfüggvények esetére. Egydetermináns esetben, mint említettük, a másodrendü sürüségmátrix kifejezhető az elsőrendü sürüségmátrix segítségével, korrelált esetben azonban nem, megjelenik egy további, kumulánsnak nevezett tag is. Az első gondolat az lenne, hogy a kötésrendet a kicserélődési tagon kívül a kumulánst is figyelembe véve definiálnánk. Ez azt is jelentené, hogy alkalmazzuk a kötésrend ,statisztikus” értelmezését a korrelált esetre is. Ennek a látszólag nagyon vonzó megközelítésnek azonban van egy komoly hátulütője: ha a $\mathrm{H}_{2}$ molekula Heitler-London-féle hullámfüggvényére alkalmazzuk, akkor egzaktul 0 ,kötésrendet” kapunk, pedig ez a hullámfüggvény már számot tudott adni a kémiai kötés meglétéről. Hasonlóan, az ún. Weinbaum-féle hullámfüggvényre ${ }^{16}$ (azaz a minimális bázis keretében egzakt „,full CI" hullámfüggvényre) ez a megközelítés mindössze egy 0,39-es értéket ad, amit sehogyan sem lehet kötésrendnek tekinteni.

Ezért én azt javasoltam ${ }^{10}$, hogy korrelált hullámfüggvények esetén is csak a kicserélődéssel dolgozzunk, vagyis lényegében ugyanazokat a képleteket használjuk a kötésrendek és vegyértékek számítására, mint az egydetermináns esetben. Ekkor kémiailag „értelmes” kötésrendeket és vegyértékeket kapunk, de a vegyértékek még az egyensúlyi magkonfigurációknál sem lesznek szigorúan egyenlőek a kötésrendek összegeivel, s minden atomon megjelenik egy kisebb-nagyobb szabad vegyérték is.

Nemrég felismertem, hogy ehhez a számítási módszerhez egy kisebb korrekciót kell bevezetni ${ }^{16}$. Ugyanis kiderült, hogy ha egy szingulett etilén molekula két triplett metilénre való disszociációját vizsgáljuk, akkor a nagy $\mathrm{C}-\mathrm{C}$ távolságoknál nem kapjuk egzaktul ugyanazokat a $\mathrm{C}-\mathrm{H}$ kötésrendeket, mint amikor egy metilént egyedül számolunk. Ennek a korrekciós tagnak az elmélete sokkal nehézkesebb, mint a kiszámítása, ezért itt csak azt hangsúlyozom, hogy a korrekció minden vizsgált esetben nagyon kicsi volt, kizárólag a teljesen korrekt disszociációs tulajdonságok biztosítása miatt érdemes alkalmazni.

\section{Effektív atompályák}

A molekulák kvalitatív és kvantitatív leírása közötti viszonnyal kapcsolatosak az „effektív atompályákra” vonatkozó eredményeim ${ }^{17}$ is. Ezek lehetővé teszik az elektronszerkezetre a minimális bázis segítségével kapott szemléletes megfontolások a posteriori alátámasztását a számítások eredményei alapján.
A mai számításokban minden atomon számos bázisfüggvényt veszünk fel, és ezek mindegyike többé vagy kevésbé hozzájárul a molekulapályák felépítéséhez. Minél több bázisfüggvényt használunk, annál jobb eredményre számíthatunk, de közben egyre inkább elveszítjük azt a szemléletes képet, hogy mondjuk egy szénatomnak van egy $1 s$ törzse és négy $2 s$, ill. $2 p$ vegyértékpályája (esetleg ezek hibridjei).

Ezt a látszólagos ellentmondást úgy sikerült feloldanom, hogy megkerestem az egyes atomokon centrált bázisfüggvényeknek azokat a lineáris kombinációit, amelyekkel az egyes atomok ténylegesen hozzájárulnak a molekulapályák felépítéséhez - míg az összes többi szerepe elhanyagolható. Ezeket az effektív atompályákat több különböző, de egymással ekvivalens módszerrel is meg lehet határozni, ezek közül a legegyszerübb az, ha a molekulapályákat egy olyan uniter transzformációnak vetjük alá, amellyel maximalizáljuk az egyes molekulapályákból $a z$ adott atomra jutó Mulliken-féle nettó populációt. (Az uniter transzformációk nem változtatják meg a molekula sokelektronos hullámfüggvényét, csak annak a felírását.) A transzformáció után kapott molekulapályáknak az adott atomra jutó komponensei lesznek az effektív atompályák ${ }^{17,18}$. Ezek normálás után egy ortonormált atomi bázist alkotnak. A tapasztalat szerint minden nemhipervalens atomon éppen annyi nem elhanyagolható betöltési számmal (azaz az említett Mulliken-féle nettó populációs hozzájárulással) rendelkező effektív atompálya van, amennyi pálya van az atom klasszikus minimális bázisában: hidrogénre 1, első sorbeli elemekre 5, második sorbeliekre 9, stb. Egyes esetekben ezek majdnem tiszta $s$ vagy $p$-pályák, máskor ilyenek hibridjei. Hipervalens esetekben megjelenik 3-5 kicsi, de nem elhanyagolható betöltési számmal rendelkező $d$-jellegü pálya is, amelyek a „,back-donationt” írják le. Én az effektív minimális bázis (plusz esetleges $d$-pályák) fogalmának komoly konceptuális jelentőséget tulajdonítok.

Az effektív atomi bázist a 3D analízis esetére is általánosítani lehetett, ehhez a nettó atomi populáció $3 \mathrm{D}$ analógját kellett definiálni ${ }^{19}$. A konklúziók is teljesen hasonlatosak voltak a Hilbert-térbeli analízis esetéhez. Itt csak egy - szerintem érdekes - alkalmazásra térnék ki: a „fuzzy atom” formalizmussal akkor is megkereshetők az effektív atompályák, ha a számítást síkhullám bázisban végeztük ${ }^{20}$. Ezek száma és $s$-, $p$ - vagy $d$-tipusú jellege itt is megfelel a szokásos minimális bázisoknak, pedig itt semmiféle szögektől függő elemet nem vittünk be kívülről a számításba. Ebből a szempontból elmondhatjuk, hogy a tapasztalat szerint „vannak atompályák a molekulákban”.

\section{0. Összefoglaló}

Ebben a szubjektív áttekintésben beszámoltam a kvantumkémiában való pályafutásom kezdeteiröl, majd arról, hogy az 1970-es évek végétől fó kutatási területemnek a molekulák fizikai és kémiai leírása közötti kapcsolatok keresését tekintettem. (Idevonatkozó eredményeim részletes 
összefoglalását nemrég megjelent monográfiámban ${ }^{12}$ adtam meg.) Az ebből a célból kifejlesztett CHA formalizmus gyakorlatilag legfontosabb eredménye a kötésrend- és vegyértékindexek bevezetése volt, amelyek a megfelelö hagyományos kémiai fogalmak kvantummechanikai megfelelöinek tekinthetők. Mivel sajnos nem létezik egyértelmű meghatározás arra, hogy mi is egy atom egy molekulán belül, a szóban-forgó indexek definícióját megadtuk a két elterjedt molekulán belüli atomfogalomra, a „Hilbert-térbeli” és a háromdimenziós atomdefinícióra is. Szót ejtettünk az effektív atompályákról is, melyek lehetővé teszik elemi elektronszerkezeti megfontolásoknak a modern számítások alapján való alátámasztását.

\section{Hivatkozások}

1. М. Г. Веселов, Элементарная Квантовая Теория Атомов и Молекул. Физматгиз, Москва, 1962.

2. H. A. Bethe, Intermediate Quantum Mechanics, Benjamin, New York-Amsterdam, 1964. https://doi.org/10.1201/9780429493645-2

3. I. Mayer, Acta Phys. Hung. 1971, 30, 373-379. https://doi.org/10.1007/BF03157084

4. I. Mayer, Simple Theorems, Proofs, and Derivations in Quantum Chemistry, Kluwer Academic/Plenum Publishers, New York, 2003.

https://doi.org/10.1007/978-1-4757-6519-9

5. I. Mayer, The Spin Projected Extended Hartree - Fock Method. Advances Quantum Chem. 1980 12, 189-262. https://doi.org/10.1016/S0065-3276(08)60317-2

6. I. Mayer, Intern. J. Quantum Chem. 1983, 23, 341-363. https://doi.org/10.1002/qua.560230203

7. I Mayer, Chem. Phys. Letters, 1983, 97, 270- 274. https://doi.org/10.1016/0009-2614(83)80005-0

8. K. B Wiberg, Tetrahedron, 1967 24, 1083 -1096. https://doi.org/10.1016/0040-4020(68)88057-3

9. M.S. de Gianbiagi, M. Gianbiagi and F. E. Jorge, Theor. Chim. Acta 1985 68, 337-341. https://doi.org/10.1007/BF00529054

10. I. Mayer, Intern. J. Quantum Chem. 1986 29, 73-84. https://doi.org/10.1002/qua.560290108

11. I. Mayer, J. Phys. Chem A. 2014 118, 2543-2546. $\mathrm{https} / / /$ doi.org/10.1021/jp501232u

12. I. Mayer, Bond Orders and Energy Components: Extracting Chemical Information from Molecular Wave Functions, CRC Press, Boca Raton-London-New York, 2017. https://doi.org/10.1201/9781315374895

13. J.G. Ángyán, M. Loos and I. Mayer, J. Phys. Chem. 1994 98, 5244- 5248. https://doi.org/10.1021/j100071a013

14. I. Bakó, A. Stirling, A. P. Seitsonen and I. Mayer, Chem. Phys. Letters 2013 563, 97-101. https://doi.org/10.1016/j.cplett.2013.01.059

15. I. Mayer and A. Hamza, Intern. J. Quantum Chem. 2005 103, 798-807. https://doi.org/10.1002/qua.20561

16. I. Mayer, Chem. Phys. Letters, 2012 544, 83-86. https://doi.org/10.1016/j.cplett.2012.07.003

17. I. Mayer, Chem. Phys. Letters, 1995 242, 499-506. https://doi.org/10.1016/0009-2614(95)00748-S

18. I. Mayer, Intern. J. Quantum Chem. Quantum Chem. Symp. 2014 114, 1041-1047. https://doi.org/10.1002/qua.24623

19. I. Mayer and P. Salvador, J. Chem. Phys. 2009 130, 234106, 1-6. https://doi.org/10.1063/1.3153482

20. I. Mayer, I. Bakó and A. Stirling, J. Phys. Chem. A, 2011 115, 12733-12737. https://doi.org/10.1021/jp2036923

\section{Bond Order and Valence Indices}

In this subjective account I have sketched the starts of my quantum chemical carrier: the first decade was mainly devoted to the development of Löwdin's spin-projected extended Hartree-Fock method. Since the end of 70-es my main research field has been the search for connections between the physical and chemical descriptions of molecular systems. For that reason I first developed a generalization of the second quantization formalism for non-orthogonal basis orbitals, owing to the great chemical significance of the overlaps between the orbitals of the neighboring atoms. A projective integral approximation permitted to represent the molecular Hamiltonian as a sum of genuine one- and two-center terms and some finite basis corrections. This formalism has been named "chemical Hamiltonian approach", CHA. (Its analogue was also utilized for developing BSSE-free intermolecular CHA techniques.)

The diatomic components of the Hamiltonian have been further decomposed into terms of different physical nature. The expectation value of the term describing the point-charge approximation of the diatomic electrostatic interaction contains a non-classical exchange term. It was found that its values obtained by omitting a common coefficient are always close to the relevant classical chemical values of bond multiplicity, so the formula was accepted as the definition of quantum mechanical bond order

$$
{ }_{A B}^{B}=\Sigma_{(\mu \in A)^{\Sigma}}(v \in B)^{(\mathbf{D S})} \mu v^{(\mathbf{D S})} v \mu
$$

where $\mathbf{D}$ is the unusual density matrix and $\mathbf{S}$ is the overlap matrix, and the restriction $\mu \in A$ indicates that the summation runs over the basis orbitals centered on atom $\mathrm{A}$. In the open-shell (including UHF) case there is also a similar term containing the spin-density matrix. The bond order indices are widely used in the literature for investigating the most different chemical problems.

Different properties of the bond order index have been discussed. The simplest systems were analyzed by paper and pencil. It was shown that a strictly localized unpolarized two-electron bond treated at the minimal basis level gives a bond order exactly equal to 1 . If there are two or three such bonds between the atoms, one gets exactly 2 or 3 . However, if the bonding and antibonding orbitals formed of the same atomic hybrids are both doubly occupied, they cancel each other and the bond order is exactly 0 . Similarly, a three-center two-electron bond generates a bond order $1 / 4$ between the outer atoms, even if they are far from each other. (In diborane there are two such bonds, leading to a B-B bond order of $1 / 2$, important for the stability of this molecule.) For larger molecules and/or if a larger basis is used, the bond orders are not simple integers, but always are close to their values assumed by chemists. The bond order index reduces to the Wigner-index of the semiempirical CNDO theory in case of orthonormalized orbitals. A deeper theoretical understanding was obtained by studying the relations to the diatomic component of the exchange part of the second order density matrix and the role of self-repulsion 
of delocalized electrons in bonding. The different problems connected with the generalization of the bond orders for the correlated wave functions are also briefly discussed.. Also, it is discussed that the approach first developed for the "Hilbert-space analysis" may be generalized for the case of 3-dimensional analysis, too. The "fuzzy atoms" formalism permits to calculate bond orders and valences even if the calculations are performed by using plane wave basis, without involving any atom-centered functions.

The closely related concepts of valence indices is also introduced and discussed. It is defined as

$$
V_{A}=2 Q_{A}-\Sigma(\mu, v \in A)^{(\mathbf{D S})} \mu v^{(\mathbf{D S})} v \mu
$$

where $Q_{A}$ is Mulliken's gtoss electronic population of atom A. For closed-shell SCF wave functions it is equal to the sum of bond orders of atom A, formed with other atoms:

$$
V_{A}=\Sigma_{[B ; B \neq A)^{B} A B}
$$

For open-shell or correlated systems a "free valence" $\mathrm{F}_{\mathrm{A}}$ also appears on the right-hand side.

Finally the concept of effective atomic orbitals is described. These orbitals are extracted from the results of calculations, but their number and character does closely correspond to the minimal basis sets one often uses in qualitative discussions of molecular electronic structure, thus giving a strong corroboration for these elementary considerations. In the case of plane wave calculations, the effective atomic orbitals obtained by using "fuzzy atoms" formalism resemble the usual minimal basis $s$-, $p$ - and $d$-orbitals, although no angle-dependent elements was introduced externally in the calculations. 